\title{
TRANSFORMATION TOWARD E-LEARNING: EXPERIENCE FROM THE SUDDEN SHIFT TO E-COURSES AT COVID-19 TIME IN CENTRAL EUROPEAN COUNTRIES; STUDENTS' SATISFACTION PERSPECTIVE
}

\author{
Pierre Alassaf ${ }^{1}$, Zsigmond Gábor Szalay ${ }^{2}$ \\ ${ }^{1} \mathrm{PhD}$ student, ${ }^{2}$ associate professor \\ ${ }^{1}$ Doctoral School of Management and Business Administration, Szent Istvan University, \\ ${ }^{2}$ Faculty of Economics and Social Sciences, Szent Istvan University \\ E-mail: ${ }^{1}$ pierrealassaf@hotmail.com, ${ }^{2}$ szalay.zsigmond.gabor@szie.hu
}

\begin{abstract}
This study aims to evaluate transforming toward online-learning, concerning students' satisfaction, social presence and students' intention to continue with e-learning in Central European countries, taking the case of Hungarian higher education online courses during COVID- 19 measures.

This study finds that masters and undergraduate students' satisfaction and social presence of online learning courses are neutral with little bias to be positive, also satisfaction has the key role in affecting student's intention to continue with future online-learning.
\end{abstract}

Keywords: students' satisfaction, social presence, student's intention, online learning, Higher education

JEL classification: $121,031,030$

LCC: LC165-182, LC1022-1022.25, T10.5-11.9

\section{Introduction}

The advancement in technologies and communications accompanied with the integration among disciplines such as education and computer science, has evolved learning to the point that needs an accessible environment supplying the necessary educational materials and tools (Ryan, 2016), such environment have been available by implementing of e-learning concept which is considering an essential tool of future learning, this new learning concept brings another the key mission for universities and business organizations to find best practices to integrate e-learning into their educating and training processes (Frehywot et al., 2013).

The difference in medium and environment between e-learning and conventional learning put some obstacles in the context of communication and interacting, one of them is social presence feelings in the digital environment, social presence identified as a solution for students to participate and cope online successfully and backup the satisfaction degree of online-courses (Cobb, 2009), in turn the successful e-learning experience for the learner may create the motivation and intention to continue with e-learning courses in future (Reio et al., 2013; Mtebe and Raisamo, 2014) .

As a consequence of Corona virus Covid-19, in spring of 2020, many schools, colleges and universities have transformed in a hurry towards e-learning (or on-line learning), with some experience in this regard for some of them or may it be totally a new experience for others.

Today we have the opportunity to evaluate concepts of social presence, satisfaction and intention to proceed with e-learning on the ground by the time of shifting toward e-learning 
process while this experience is still alive and fresh in students' minds, taking Hungarian under graduated and master students as an example of transformation toward online learning experience in Central Europe.

\section{Literature review}

Simply Fatma (2013) has defined e-learning as skills and knowledge acquirement through courses over internet by means of electronic technologies (PCs, networks, modems, etc....) this definition describes the final goal of e-learning which is grasping the knowledge and describes the medium; internet and electronic devices, but it didn't mention the interacting process between two ends of e-learning those are trainee and trainer as 'transceivers', or internet on one end as a source and learner as an interactive 'transceiver' on the other end.

From another perspective Wiers-Jenssen, Stensaker and Grogaard (2002) have a critical opinion about the core idea of Fatma's definition but precedes her study, he argued that education is not only skills and knowledge acquirement but it also includes learner's progression through self-evolution and social development.

In seeking of making comparisons between online and conventional learning, students' satisfaction was posed as an important basis of comparison, on one hand Fortune, Shifflett and Sibley (2006) found lower overall satisfaction in online courses, but Artz (2006) found adult learners' satisfaction was more in online courses, a third group of researchers as Allen, Bourhis, Burrell and Mabry (2002) found no difference in students' satisfaction between conventional and online courses, and most of researchers have reached the same result (Lim et al., 2008).

In the following, more detailed discussions about social presence, satisfaction of online courses and learners' intention to continue with e-learning, due to their importance and relevance to the objectives of the study.

\section{Social presence}

There is no unique agreed definition of social presence in the studies, which put huge difficulties for concerns to reach a solid perception about the nature of this concept (Patrick, 2009).

Basically, in the literature of telecommunications, we can find the roots of social presence notion (Cobb, 2009). Picciano (2002) has expressed social presence as learner's perceiving of his existence in online course and belonging to it, in another way Gunawardena and Zittle (1997) have defined social presence as the extent to which an individual is considered as "real person" in mediated- communication, Gunawardena and Zittle (1997) in their understanding of social presence depend on the analyzing of Short, Williams and Christie (1976) study which explained social presence as "the degree of salience of the other person in the interaction and the consequent salience of the interpersonal relationships" (p. 65), Tu and McIssac (2002) also backing the notion of mutual relationship between social presence and interaction, they found if the degree of interaction in online course should be raised, the social presence level should be raised too, and they also noticed that, in the case of online courses, the lack of physical existence, faces' cues, and nonverbal communication, minifying social presence of learners (Tu and McIssac, 2002).

\section{Students satisfaction}

Looking to students in online course as customers to online learning service, the common definition of satisfaction matches this case; It is a measure of how service and/or product 
provided by an organization meets or exceeds customer's expectation, hence, Tse and Wilton's (1988) defined satisfaction as responses of customers to their evaluating of perceived contradiction between expectations before receiving the service and actual performance.

More specifically Oliver (1999) described the satisfaction of students as the gap between what was expected from a service and what was delivered.

From more related perspective linked to the interaction between user and computer, Lindgaard and Dudek (2003) described users satisfaction as the expertise of impacts acquired from the interaction between technology and user, this interaction has an influence via several factors on the satisfaction, some of those factors in the case of online courses: the environment, technology itself, System and course designs, instructor and the learners (Teo, 2014).

\section{Students' intentions to participate in future online courses}

Tarhini, Hone and Liu (2013) described intention as the direct predecessor of using action, giving signs of person's preparation to perform a specific behavior.

More specifically, Puzziferro (2008) found that the intention to use system in the case of online courses is driven by users' motives, beside to the motives Chen and Tseng (2012) determined that also self-efficacy have a positive impact on this intention, and founded a negative impact of anxiety toward using computer, here, Venkatesh, Morris, Davis and Davis (2003) noted that technology usage intention related positively with performance expectance.

In same context Esterhuyse et al. (2016) argued that e-learning success is preceded by students' satisfaction and intention to utilize e-learning system which are vital factors of successful elearning process.

\section{Methodology}

This research to achieve its objectives have to measure Higher education students' Satisfaction, Social presence and Intentions to continue with e-courses in the future in online learning environment, this needs to define instruments that measures those variables and develop the scales to match the case, a deep review of literature concerning those measures was carried out, scales development for this research is explained in following paragraphs.

\section{Measuring Social Presence in online courses}

Patrick (2009) argued that most of studies concerns about measuring social presence, depend on the scales developed by one or more of key studies in this regard; Rourke et al. (2001), Tu (2002) and the most famous study Gunawardena and Zittle (1997).

The most famous social presence scale has been designed by Gunawardena and Zittle's (1997) study testing the potentials of social presence to predict satisfaction in CMC conditions, they used in their analyzing approach short et al.'s (1976) model and Gunawardena's (1995) deep discussions of literature, the proposed questionnaire consists of 52 items selected for the measurements of the research interest, 14 of them for measuring social presence and 10 for participant's' satisfaction, the reliability for social presence scale depending on Cronbach's Alpha was 0.88, and for satisfaction's was 0.87 (Gunawardena and Zittle, 1997).

Here, in the following, some examples of successor researches depended on by Gunawardena and Zittle's (1997) scale in measuring social presence. 
Cobb (2009) has discussed the satisfaction and social presence scales developed by Gunawardena and Zittle (1997) by conducting a new research concentrating on online learning, the outcomes of this study was supportive to Gunawardena and Zittle's (1997) that the scales are still realiable, valid, and recommended to be used in future researches, Cronbach's Alpha in cobb's study reported 0.87 for social presence scale and 0.85 for satisfaction scale.

Also, Strong Irby, Wynn and McClure (2012) conducted a study in conditions of online courses to measure students' cognitions of the social presence, satisfaction, and learning environment, using already designed surveys known in literature, social presence and satisfaction scales matches those used in Cobb (2009) study, Depending on ex post facto the internal consistency of the scales were 0.89 for satisfaction's, and 0.94 for social presence's (Strong, 2012).

In same regards Reio and Crim (2013) research concerned in predicting the role of students' social presence and satisfaction in their intention to enroll online, for this purpose they conduct a survey using Gunawardena and Zittle (1997) scale for measuring social presence, The reliability of Rio et al. (2013) scale depended on reliability of the original scales (Reio, 2013).

By the end of this paragraph, the researcher of this study decided to use the scale developed by Gunawardena and Zittle (1997) as it is widely reused in many researches and have a continued tested reliability, making some modification to the scale phrases to fit in the research context.

\section{Measuring Satisfaction in online courses}

This study leans in developing its scale of measuring students' satisfaction in online courses basically on three studies, the first is Gunawardena and Zittle (1997), its satisfaction scale has been widely reused by later studies such as cobb (2009) and strong et al. (2012) those have discussed in the previous paragraph, the reliability of Satisfaction scale of Gunawardena and Zittle (1997), cobb (2009) studies using Cronbach' Alpha was reported 0.87 and 0.85 respectively and the internal consistency of the satisfaction scale depending on (ex post facto) was 0.89 in strong et al.’s (2012).

The second study this research used in developing satisfaction scale is Esterhuyse et al. (2016) that depended basically on Chatzoglou et al. (2009) model and the literature, the reliability using Cronbach's Alpha coefficients for satisfaction was reported 0.89.

Finally, the third scale used in building this study's scale is Morton (1993) who developed satisfaction of learning experiences scale with reported reliability of 0.81 using Cronbach's Alfa, the main objective of his study is to examine the socialization operation for new employees from a learning point of view, and his satisfaction scale consists of 4 items out of 34 items designed to evaluate socialization related learning experiences (Morton, 1993), this scale also reused by Reio et al. (2013) research discussed in the previous paragraph.

Gunawardena and Zittle (1997), Esterhuyse et al. (2016) and Morton (1993) scales regarding measuring students' satisfaction are covering satisfaction measuring aspects found in literatures concerning online courses and e-learning, and the developed expanded satisfaction scale for online learners this research has abstracted from above mentioned three scales with some modifications of original phrases to fit the context of the study and adding (more specifically; repeating) measuring items regard the new development in the medium as voice communication and video interacting which haven't been used by online courses by the time of some original studies those focused on texting as a communication online method, then the new scale exerted to factor analysis and tested using Cronbach' alpha. 


\section{Measuring students' intentions toward shifting to online courses in the future}

Esterhuyse, Scholtz and Venter (2016) in their research have developed besides to the satisfaction scale an intention scale, the intention scale was built basically from Chatzoglou et al. (2009) modal and reviewing the literature, that study developed those scales to test satisfaction and intention in corporate environment.

Finally, Esterhuyse, Scholtz and Venter (2016) proposed a 4 items scale to measure intention, this study depends on it in measuring the intentions of students who shifted toward studying online if they will continue with online courses in case of being available in the future. The original Esterhuyse et al.'s (2016) scale reliability tested by Cronbach's alpha coefficient reported 0.92 .

\section{Validity and reliability of the scales}

This study has tested the reliability of used scale by reporting Cronbach's Alpha coefficient.

Cronbach' Alpha for Satisfaction, Social presence and intent reported 0.94, 0.75, 0.87 respectively, those exceeds the minimum accepted value 0.7 identified by Nunnally (1978), this means those scales are reliable to use in future studies.

As this study has developed students' satisfaction scale from three sub-scales; Gunawardena and Zittle's (1997), Esterhuyse et al.'s (2016) and Morton's (1993), this research retest the embedded three sub-scales individually to evaluate the continued reliability of each of them using Cronbach's Alpha coefficient that reported 0.84, 0.9, 0.89 respectively, so this study confirm the continued reliability of satisfaction scales of the three mentioned studies which consist with Cobb (2009) finding about Gunawardena and Zittle's (1997) scales and recommend future researches to reuse them in the regards of interests.

This study have also conducted factor analysis on the new satisfaction scale, the result of this analysis confirmed the 18 items of the new scale as the test gives two main factors the first comply with two first original scales; Gunawardena and Zittle's (1997), Esterhuyse et al.'s (2016) and the second matches with the Morton's (1993) scale, as a result all 18 items are used in the new scale.

As a result, this research developed new comprehensive student's satisfaction scale with reliability reported 0.94 using Cronbach's Alpha, and highly recommend researchers to use it in their future researches, as Carmines and Zeller (1979) stated that to use an instrument widely in studies it should report Cronbach's Alpha of at least 0.80.

Validity of the scales gained from two ways, first from the validities of original scales those also reused by several successor studies, and the content and face validity of the scales were evaluated by e-learning researchers in Hungary.

\section{Limitation of the study}

Vast majority of responses $93.4 \%$ came from Szent Istvan University the place where the researcher has prepared this study, 2.3\% from Széchényi István University, 1.2\% from Corvinus University in Budapest, 3.1\% spread over the rest of Hungarian Universities. 


\section{Sample and used instrument}

The targeted sample is master and undergraduate students studying in Hungarian universities.

A questionnaire of 44 questions (items) has been distributed online via google sheet and the link shared over social media groups, emailed by Neptun System on May 21 th 2020 and stopped to receiving responses on June 10th 2020, there were two versions of questionnaire in English and in Hungarian.

The 44 questions consist of 18 items to measure students' satisfaction on online courses, 14 for social presence, 4 for students' intention to use online learning in the future when it is available. The questions used 5- points Likert Scale which is convenient to online questionnaire.

The rest 8 items contain questions for collecting information about the respondent's background (such as age, gender, study level, studying language, Hungarian or international student, etc..) for statistical reasons.

The questionnaire has received 824 responses, 4 responses have been rejected due to the lack of seriousness in the answers.

The final number of responses to be analyzed is 820 responses, 739 of them in Hungarian version and 81 in English.

\section{Sample background analyzes}

$60 \%$ of respondents are females, $37.1 \%$ are males where $2.8 \%$ preferred not to answer this question and no one chose the answer "other", one answer out 820 is missing.

$68.2 \%$ are undergraduate students, $28.2 \%$ are Master students.

87.6 of the sample are Hungarians, $12.4 \%$ are international students, this percentage is close to the percentage of international students in Higher education studying in Hungary which is $12 \%$ in 2017 (Kasza and Hangyál, 2018).

$89.6 \%$ of students studying in Hungarian, 10.2\% studying in English and one answer is missing.

The important thing is $75.1 \%$ of students having the first online study, most of them undergraduate students $(52.8 \%)$, this is important in evaluating the success of current online courses without students' affection by a previous experience.

\section{Results and discussions}

Three new variables have been calculated from the answers of the three scales used in the questionnaire, to use them in analysis, those are: overall Satisfaction, overall social presence and over all students' intention, each gives the mean answer of all items forms each scale for every response, this accomplished by using SPSS program.

Overall satisfaction of master and undergraduate students toward current shifting to online learning in Hungary is (3.1), this result is very close to the middle of 5-points Likert scale so we can say the students' satisfaction is neutral with very little bias to be positive, which could be read in two approaches, first, more efforts from higher education institutions are needed to raise students' satisfaction of online learning, from other hand it is prominent result that 
students didn't refuse the online learning and tends to accept it, so this would encourage educational institutions with some more efforts to go on with online learning and depend on elearning as a supportive learning in the next period or even think to shift to online learning in the future.

More analysis has done to compare between foreign and Hungarian students' satisfaction, Showed that there is a significant deference between International and Hungarian students concerning their satisfaction on online courses in 9 out of 18 items measuring students' satisfaction, the International students are more satisfied in this experience, this result reaffirmed by using independent sample $\mathrm{T}$ test on overall students' satisfaction, this research couldn't explains this deference in context of this study especially that a fairly adjacent percentage of International (69\%) and Hungarian (76\%) students are experiences online courses for the first time, and there is no recognized difference between age average of the two groups.

The students' overall social presence feeling in current online learning is (3.2), this result is close to the middle of the scale so we can say the students' social presence feeling is neutral with a little bias to be positive, which seems a good result for a new online learning experience, to explain this result more precisely, this result should be compared to students' social presence feeling in conventional courses, the article suggest this subject for a future research.

Overall intention of master and undergraduate students to have online learning in future is (3), this result stuck to the middle of the scale, this means students' intention is neutral, this result gives an opportunity to the educational institutions to effect this intention if they want to proceeds with online learning, to do that they have to know the factors affecting students' intention to continue with online courses, this study is lighting on some of them by calculating the correlation and regression among Intention, satisfaction and social presence.

By using independent sample $\mathrm{T}$ test, it found that overall social presence feeling in online courses and overall intention to attend future online courses are more among international students $(\mathrm{M}=3.5,3.34$ respectively) than Hungarians $(\mathrm{M}=3.2,2.9$ respectively), this result need a further research to explain it.

In the same way, the study has used independent sample $\mathrm{T}$ test, to compare between master and undergraduate student in their satisfaction, social presence feeling and intentions toward online learning, also the same test done to compare between students who had a previous online learning with the newbies in this regard, all the results are showed in table. 1.

The study has conducted correlation tests among the three variables; overall Satisfaction, overall social presence and over all students' intention, to define the relation strength and direction among them, and the results are explained in the following:

Using Davis (1971) explanation of coefficient value (r), the calculated correlations shows a very strong positive relation between overall satisfaction and overall student' intentions $(\mathrm{r}=0.8$; $\mathrm{P}<0.001)$, and a substantial positive relation between overall social presence and overall student' intentions $(\mathrm{r}=0.59 ; \mathrm{P}<0.001)$.

Also, there is a very strong positive relation between overall satisfaction and overall social presence $(\mathrm{r}=0.7 ; \mathrm{P}<0.001)$. 
Table 1: overall satisfaction, Social presence and intention of higher education students toward online learning in Hungary during COVID-19 epidemic

\begin{tabular}{|c|c|c|c|c|c|}
\hline & $\begin{array}{l}\text { Higher education } \\
\text { students (Master } \\
\text { and } \\
\text { undergraduate) }\end{array}$ & Explanation & $\begin{array}{l}\text { International VS } \\
\text { Hungarian students }\end{array}$ & $\begin{array}{l}\text { Undergraduate } \\
\text { VS Master } \\
\text { students }\end{array}$ & $\begin{array}{l}\text { Newbies in } \\
\text { online learning } \\
\text { vs. Experienced } \\
\text { online learners }\end{array}$ \\
\hline $\begin{array}{l}\text { Overall } \\
\text { satisfaction } \\
(1-5)\end{array}$ & 3.1 & $\begin{array}{l}\text { Neutral } \\
\text { satisfaction with } \\
\text { little bias to be } \\
\text { positive }\end{array}$ & $\begin{array}{l}\text { International students } \\
\text { are significantly more } \\
\text { satisfied. }\end{array}$ & $\begin{array}{l}\text { Master students } \\
\text { are more satisfied }\end{array}$ & $\begin{array}{l}\text { Who have } \\
\text { previous online } \\
\text { experience are } \\
\text { more satisfied }\end{array}$ \\
\hline $\begin{array}{l}\text { Overall } \\
\text { social } \\
\text { presence } \\
\text { feeling (1-5) }\end{array}$ & 3.2 & 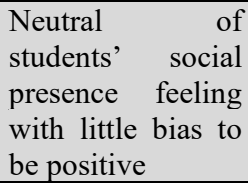 & $\begin{array}{l}\text { International students } \\
\text { are significantly } \\
\text { having more social } \\
\text { presence feeling. }\end{array}$ & $\begin{array}{lr}\text { Master } & \text { students } \\
\text { having } & \text { more } \\
\text { social } & \text { presence } \\
\text { feeling } & \end{array}$ & $\begin{array}{l}\text { No significant } \\
\text { difference }\end{array}$ \\
\hline $\begin{array}{l}\text { Overall } \\
\text { intention to } \\
\text { have online } \\
\text { learning in } \\
\text { future (1-5). }\end{array}$ & 3 & Neutral & $\begin{array}{l}\text { International students } \\
\text { are significantly } \\
\text { having more } \\
\text { intention to have } \\
\text { online learning in } \\
\text { future. }\end{array}$ & $\begin{array}{l}\text { No significant } \\
\text { difference }\end{array}$ & $\begin{array}{l}\text { Who have } \\
\text { previous online } \\
\text { experience have } \\
\text { more intention to } \\
\text { continue with e- } \\
\text { learning }\end{array}$ \\
\hline
\end{tabular}

Source: Authors' analysis, 2020.

Furthermore, a multiple regression analysis has been conducted between overall students' intention as dependent variable and overall Satisfaction, overall social presence, age, gender, foreign or international student, study level and previous online studying experience as independent variables, to know the effectiveness of these variables in predicting students' intention to continue with online learning, see table. 2.

Table 2: Multiple regression analysis between overall students' intention as dependent variable and study independent variables

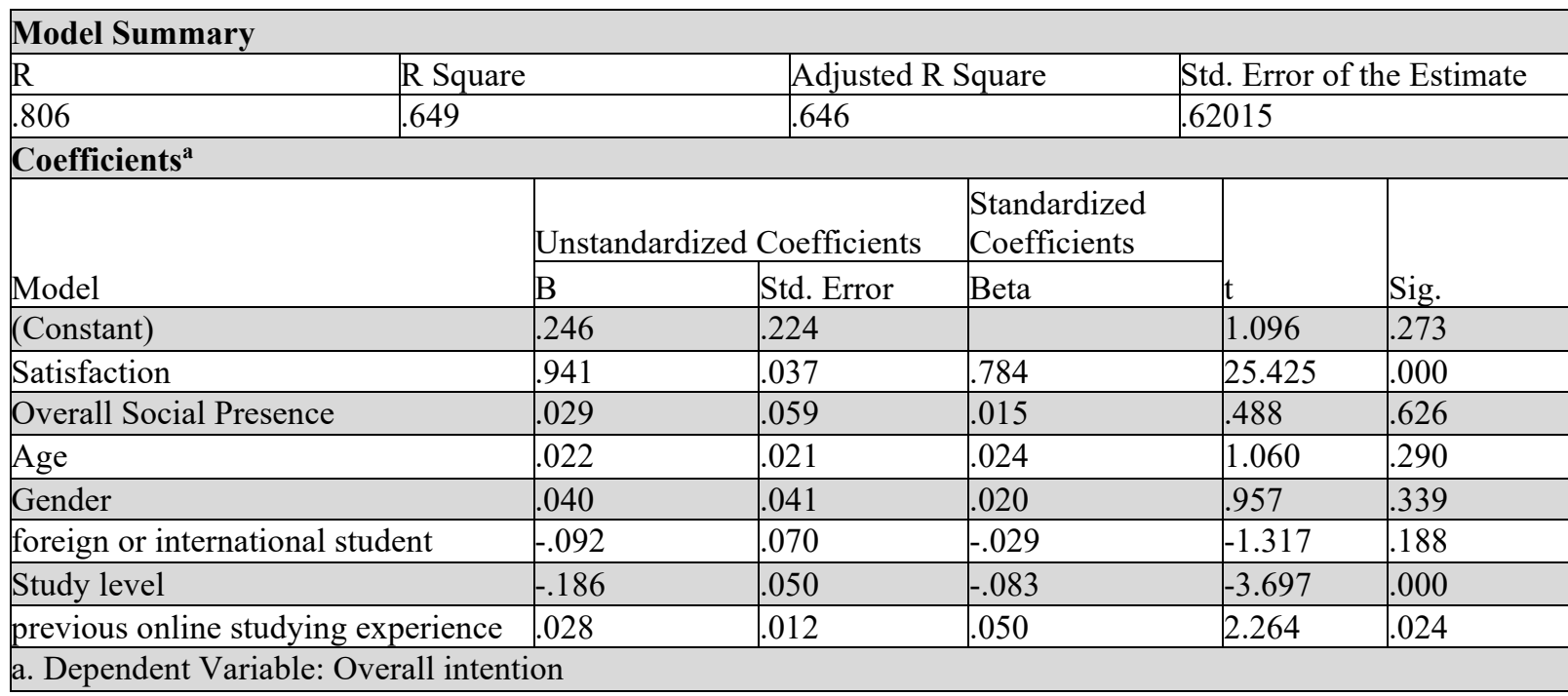

Source: Authors' analysis, 2020.

The regression analysis shows that only Satisfaction, study level and self-evaluation of previous online learning have a significant relation with students' intention, where study level and evaluation of previous online learning self-experience have a very weak influence on intention $(B=0.18,0.028$ respectively), while satisfaction has the key role on affecting this intention $(B=$ $0.94)$ taking in regards that Adjusted $R$ square is 0.65 which means overall satisfaction explains about $65 \%$ of overall students intention changes in this context. 
Another regression analysis conducted to evaluate the influence of social presence feeling on the student's satisfaction in online courses, the result shows a significant influence of the overall social presence on overall student's satisfaction $(\mathrm{B}=1.16 ; \mathrm{P}<0.001)$ and Adjusted $\mathrm{R}$ square is 0.53 which means the overall social presence explains about $53 \%$ of overall students' satisfaction changes in this context, this result presents satisfaction as a mediator variable between social presence and student intention toward taking online courses in the future.

\section{Conclusion}

The study presents a new reliable developed Satisfaction scale, and it recommends researchers to use it, in addition to use its constructing sub-scales; the satisfaction scales of: Gunawardena and Zittle (1997), Esterhuyse et al. (2016) and Morton (1993) as this study reaffirmed their continued reliability.

Also, this study reaffirmed continued reliability of Gunawardena and Zittle (1997) social presence scale, and intention Esterhuyse et al.'s (2016) scale, and it encourage to reuse them in future studies.

The research finds that Higher education (masters and undergraduate) students' overall satisfaction and overall social presence is neutral- with little bias to be positive- on shifting towards online learning courses in Hungarian universities during COVID-19 epidemic measures, and there is a significant influence of the overall social presence on overall student's satisfaction, also the study level (master or undergraduate) and evaluation of previous online learning self-experience have a very weak influence on students' intention while satisfaction has the key role on affecting this intention to go on with online learning in the future.

Here, the study recommends educational institutions, if they want to proceeds with online learning, to focus on increasing students' satisfactions and social presence feeling.

Another finding of the study that overall international students' satisfaction, social presence feeling in online courses and overall intention to attend future online courses are more than Hungarians', this result need a further research to explain it.

\section{References}

1. Allen, M., Bourhis, J., Burrell, N., and Mabry, E. (2002): Comparing student satisfaction with distance education to traditional classroom in higher education: A meta- analysis. The American Journal of Distance Education, 16(2), 83- 97. DOI: https://doi.org/10.1207/S15389286AJDE1602_3.

2. Artz, P. (2006): Improving student satisfaction in online adult education. In C. M. Crawford, R. Carlsen, K. McFerrin, J. Price, R. Weber, D. A. Willis (Eds.), Proceedings of SITE 2006- Society for Information Technology and Teacher Education International Conference, pp. 233- 238. Association for the Advancement of Computing in Education. (AACE). Orlando, Florida, USA. ISBN 978-1-88009458-7. [online]: https://www.learntechlib.org/p/22038/: [Accessed on Jun 1st 2020].

3. Carmines, E. G., and Zeller, R. A. (1979): Reliability and validity assessment. Beverly Hills, CA: Sage Publications. DOI: https://dx.doi.org/10.4135/9781412985642.

4. Chatzoglou, P., Sarigiannidis, L., Vraimaki, E., and Diamantidis, A. (2009): Investigating Greek employees' intention to use web- based training. Computers and Education. 53(3), 877- 889. 
5. Chen, H. R., and Tseng, H. F. (2012): Factors that influence acceptance of web-based e-learning system for the in-service education of junior high school teachers in Taiwan. Evaluation and Program Planning, 35(3), 398- 406. DOI: 10.1016/j.evalprogplan.2011.11.007.

6. Cobb, S. C. (2009): Social presence and online learning: A current view from a research perspective. Journal of Interactive Online Learning, 8 (3), 241-254.

7. Esterhuyse, M. P., Scholtz, B. M., and Venter, D. (2016): Intention to use and satisfaction of e-learning for training in the corporate context. Interdisciplinary journal of information, knowledge, and management. 11, 347- 365 . DOI: https://doi.org/10.28945/3610.

8. Fatma S. F. (2013): E-Learning Trends Issues and Challenges. International Journal of Economics, Commerce and Research. 3 (2), 1- 10.

9. Fortune, M., Shifflett, B., and Sibley, R. (2006): A comparison of online (high tech) and traditional (high touch) learning in business communication courses in Silicon Valley. Journal of Education for Business, 81(4), 210- 214.

10. Frehywot, S., Vovides, Y., Talib, Z., Ross, H., Wohltjen, H., Bedada, S., Korhumel, K., Koumare A. K., Scott, J. (2013): E-learning in medical education in resource constrained low and middle-income countries. Human resource health. (2013). 11, Article number: 4. DOI: 10.1186/1478-4491-11-4. [Available online]: https://humanresources-health.biomedcentral.com/articles/10.1186/1478-4491-11-4 [Accessed on May 12th 2020].

11. Fraser, B. J. (2002): Learning environments research: Yesterday, today and tomorrow. In: S. C. Goh and M. S. Khine (Eds.), Studies in educational learning environments: An international perspective (pp. 1-25). River Edge, NJ: World Scientific. DOI: https://doi.org/10.1142/9789812777133_0001.

12. Gunawardena, C. N. (1995): Social presence theory and implications for interaction and collaborative learning in computer conferences. International Journal of Educational Telecommunications. 1 (2/ 3), 147- 166.

13. Gunawardena, C. N., and Zittle, F. J. (1997): Social presence as a predictor of satisfaction with a computer-mediated conferencing environment. American Journal of Distance Education. 11, 8- 26.

14. Kasza, G., and Hangyál, Z. (2018): Stipendium Hungaricum scholarship holders' expectations and attitudes. Tempus Public Foundation, 2018. Széchenyi 2020 Programme, within Campus Mundi (mobility and internationalisation in higher education) Programme (project number: EFOP-3.4.2-VEKOP-15-2015-00001). ISBN 978-615-5319-57-0.

15. Lim, J., Kim, M., Chen, S., and Ryder, C. (2008): An empirical investigation of student achievement and satisfaction in different learning environments. Journal of Instructional Psychology, 35(2), 113-119. DOI: 10.1163/ej.9789004167872.i-234.32.

16. Lindgaard, G., and Dudek, C. (2003): What is this evasive beast we call user satisfaction? Interacting with Computers. 15(3), 429- 452. DOI: 10.1016/S09535438(02)00063-2.

17. Morton, S. T. (1993): Socialization- related learning, job satisfaction, and commitment for new employees in a federal agency. Unpublished doctoral dissertation. Faculty of Virginia polytechnic institute and state university. Blacksburg. Virginia.

18. Mtebe, J. S. and Raisamo, R. (2014): Investigating students' behavioral intention to adopt and use mobile learning in higher education in East Africa. The International Journal of Education and Development Using Information and Communication Technology (IJEDICT). 10 (3), 4- 20.

19. Nunnally, J.C. (1978): Psychometric theory (2nd ed.). McGraw-Hill. New York. 
20. Oliver, R. L. (1999): Whence consumer loyalty?. Journal of Marketing. 63, 33- 44. DOI: https://doi.org/10.1177/00222429990634s105.

21. Picciano, A. (2002): Beyond student perceptions; Issues of interaction, presence, and performance in an online course. Journal of asynchronous learning networks. 6 (1), 21-40. DOI: 10.24059/olj.v6i1.1870.

22. Puzziferro, M. 2008: Online technologies self-efficacy and self-regulated learning as predictors of final grade and satisfaction in college-level online courses. The American Journal of Distance Education. 22 (2), 72- $89 . \quad$ DOI: https://doi.org/10.1080/08923640802039024.

23. Ryan, J. (2016): “Asian" learners or "internationalized" learners? Taking advantage of international cultural academic flows. East Asia. 33(1), 9-24. DOI 10.1007/s12140015-9246-2.

24. Reio Jr, T. G., and Crim, S. J. (2013): Social presence and student satisfaction as predictors of online enrollment intent. American Journal of Distance Education, 27(2), 122-133. DOI: https://doi.org/10.1080/08923647.2013.775801.

25. Rourke, L., Anderson, T., Garrison, D. R., and Archer, W. (2001): Assessing social presence in screen text- based computer conferencing. Journal of distance education. 14 (2). ISSN: 0830-0445.

26. Short, J. A., Williams, E., and Christie, B. (1976): The social psychology or telecommunications. London, England; Wiley.

27. Strong, R., Irby, T. L., Wynn, J. T., McClure, M. M. (2012): Investigating Students' Satisfaction with eLearning Courses: The Effect of Learning Environment and Social Presence. Journal of Agricultural Education. 53(3), 98- 110. DOI: 10.5032/jae.2012.03098.

28. Tarhini, A., Hone, K., and Liu, X. (2013): Extending the TAM model to empirically investigate the students' behavioral intention to use e-learning in developing countries. Science and Information Conference (SAI), 732-737.

29. Teo, T. (2014): Preservice teachers' satisfaction with e-learning. Social Behavior and Personality: An International Journal. 42(1), 3-6. DOI: https://doi.org/10.2224/sbp.2014.42.1.3.

30. Tse, D. K., Wilton, P. C. (1988): Models of consumer satisfaction formation. J Mark Res, 25 (2), 204- 212. DOI: 10.2307/3172652.

31. Tu, C. H. (2002): The measurement of social presence in an online learning environment. International Journal on E-Learning, April- June, 34- 45. DOI: 10.17471/2499-4324/421.

32. Tu, C. H., and McIssac, M. (2002): The relationship of social presence and interaction in online classes. The American Journal of Distance Education. 16 (3), 131- 150. DOI: https://doi.org/10.1207/S15389286AJDE1603_2.

33. Venkatesh, V. Morris, M. G., Davis, G. B, Davis, F. D. (2003): User Acceptance of Information Technology: Toward a Unified View. MIS Quarterly, 27 (3), 425-478. DOI: $10.2307 / 30036540$.

34. Wiers-Jenssen, J., Stensaker, B., and Grogaard, J. B. (2002): Student satisfaction: Towards an empirical deconstruction of the concept. Quality in Higher Education. 8 (2), 183- 195. DOI: 10.1080/1353832022000004377. 